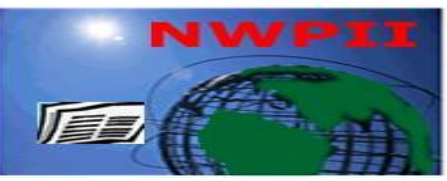

American Journal of Biomedical Sciences

ISSN: 1937-9080

nwpii.com/ajbms

\title{
Bacterial Agents of Surgical Site Infections in South-Western Nigeria
}

\author{
Olufunmilola B. Makanjuola $^{1 *}$, Olugbenga A. Olowe ${ }^{2}$, A. Folasoge Adeyankinnu ${ }^{3}$ \\ ${ }^{1}$ Department of Medical Microbiology and Parasitology, University of Ibadan, Nigeria \\ ${ }^{2}$ Department of Medical Microbiology and Parasitology, Ladoke Akintola University of Technology Ogbomoso, \\ Nigeria \\ ${ }^{3}$ Department of Medical Microbiology and Parasitology, Federal Medical Centre Abeokuta, Ogun state, Nigeria \\ Corresponding author: \\ Dr. Olufunmilola Bamidele Makanjuola. \\ Department of Medical Microbiology and Parasitology, \\ University of Ibadan, \\ P.O. Box 10314, G.P.O. Dugbe, Ibadan, Nigeria. 200001 \\ Nigeria \\ Tel: +2348034731717 \\ E-mail: funmifemi@yahoo.com
}

Received: 16 September 2013; | Revised: 6 November 2013; | Accepted: 22 November 2013

\begin{abstract}
Surgical Site Infections (SSIs) are risks associated with surgical procedures and represent a significant burden in terms of morbidity, mortality and healthcare costs. Appropriate antibiotic therapy is required to reduce this burden. The aim of this study was to determine the bacterial agents responsible for these infections and their antibiotic susceptibility pattern in order to guide the initiation of empirical therapy.

Two hundred samples from surgical sites were collected over a six-month period. They were examined microscopically and cultured aerobically. Antibiotic susceptibility testing was performed using the KirbyBauer disc diffusion technique. One hundred and sixty (160) bacterial isolates were recovered from culture of samples from surgical site infection. The predominant organism was Escherichia coli, 52(32.5\%). Others were Staphylococcus aureus 46(28.75\%; Pseudomonas aeruginosa 26 (16.25\%); Proteus species 18(11.25\%); Klebsiella species 14(8.75\%); Enterococcus species (1.25\%) and $\alpha$-haemolytic Streptococci (1.25\%). SSIs were most prevalent among Obstetrics and Gynaecology patients. Bacterial growth was $100 \%$ at the extremes of ages. The isolates were highly resistant to Erythromycin, Amoxycillin, Cotrimoxazole and Tetracycline, but susceptible to Ceftriaxone, Ofloxacin and Ciprofloxacin. Fluoroquinolones and Cephalosporins are the drugs of choice in the treatment of surgical site infections in this environment.
\end{abstract}

Keywords: antibiotic resistance, nosocomial infection, surgical site infections. 


\section{Introduction}

Surgical site infections (SSI) are ranked among the most common Healthcare-Associated Infections, along with pneumonia, urinary tract infections and blood stream infections. They cause significant morbidity, increased cost of care and prolonged hospital stay[1,2,3,4].

A definite case of surgical site infection is defined as one in which there is any skin eruption or drainage at the surgical site and is positive for bacteria by culture within 60 days of a surgical procedure[5].

Surgical wound infection is a prototype of hospital-acquired infection (HAI) and constitutes a serious problem. It is therefore used as a good index of nosocomial infection. Post operative surgical site infections remain a major source of illness and a less frequent cause of death in the surgical patient [6].

SSIs are classified into incisional SSIs or organ/space SSIs, which affect the rest of the body other than the body wall layers. A simplified system of classification categorizes surgical wounds as clean, clean-contaminated, contaminated and dirty and is used to predict the rate of infection after surgery. Before the routine use of prophylactic antibiotics, infection rates were $1-2 \%$ or less for clean wounds, 6-9\% for clean-contaminated wounds, $13-20 \%$ for contaminated wounds and about $40 \%$ for dirty wounds[7,8], Since the introduction of routine prophylactic antibiotic use, infection rates in the most contaminated groups have reduced drastically[9].

The level of bacterial burden is the most significant risk factor in determining the potential for and the incidence of infection and wound healing. Other important factors are virulence and invasive capacity of invading organism[10]. Surgical wound pathogens are usually bacterial and, in recent years, there has been a rise in the prevalence infections caused by Gram-negative organisms. These organisms have almost replaced Staphylococcus aureus in nosocomial infections [11]. It is therefore necessary to ascertain the agents of infection, especially bacteria which serve as a major and common pathogen of surgical wound infection.
The aim of this study therefore was to identify bacterial agents of SSIs and determine their antibiotics susceptibility pattern with a view to promoting prompt and effective management of such infections.

\section{Methods}

\subsection{Study design and site}

The study was conducted at Federal Medical Centre, Idi-Aba, Abeokuta, a 150 bed tertiary health hospital located in South-Western Nigeria, from June to November, 2010. A cross sectional study was carried out. All samples of surgical site infections sent to the laboratory for processing during the six-month period of the study were processed.

\subsection{Specimen collection and culture}

The samples were wound swab with accompanying request form which contained demographic and clinical information.

The wound swabs were taken from the site of surgical infection and immediately transported to the laboratory for processing. They were inoculated on both blood agar, and MacConkey agar plates. The MacConkey agar plates were incubated aerobically at $35^{\circ} \mathrm{C}$ while the blood agar was incubated in the presence of $10 \% \mathrm{CO}_{2}$ at $35^{\circ} \mathrm{C}$. Both were incubated for up to 48 hours. Gram staining was also carried out for direct examination of the sample.

Isolates were identified initially by colonial morphology and Gram stain. Standard biochemical tests were used to confirm the isolates [12]. Escherichia coli ATCC 25922 and Staphylococcus aureus ATCC 25923 were used as controls.

\subsection{Antibiotics susceptibility testing}

In vitro susceptibility of the identified organisms to the tested antibiotics was determined using Kirby Bauer disc diffusion technique [13]. Commercially available

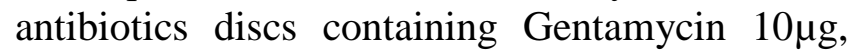
Erythromycin $15 \mu \mathrm{g}$, Augmentin $30 \mu \mathrm{g}$, Ceftriaxone $30 \mu \mathrm{g}, \quad$ Co-trimoxazole $25 \mu \mathrm{g}$, Ofloxacin $5 \mu \mathrm{g}$, Tetracycline $30 \mu \mathrm{g}$, Ciprofloxacin

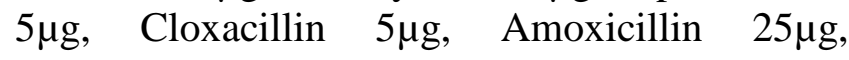


Cefuroxime $30 \mu \mathrm{g}$, and Ceftazidime $30 \mu \mathrm{g}$ were used in this study. Zones of inhibition after incubation were observed and the diameters of inhibition zones were measured in millimeters using a caliper. The interpretation of the measurements as sensitive, intermediate, resistant was made according to CLSI recommendations [14].

\subsection{Data processing}

Data was entered into Microsoft excel and analyzed using SPSS software version 16. Frequency tables were used to summarize the data.

\section{Results}

A total number of 200 samples were collected from both male and female of different age groups and the percentage with bacterial growth is as shown. The male to female ratio was $1 ; 2.5$ with a mean age of 26.1 years. All samples obtained from the extremes of ages yielded bacterial growth for both male and female. Most samples were obtained from young individuals between the ages of 20 and 40 .

Table1: Distribution of samples by age and sex

\begin{tabular}{|l|ll|ll|ll|}
\hline & \multicolumn{3}{|c|}{ Male } & \multicolumn{2}{|c|}{ Female } & \multicolumn{2}{c|}{ Total } \\
$\begin{array}{l}\text { Age } \\
\text { range } \\
\text { (years })\end{array}$ & $\begin{array}{l}\text { No of } \\
\text { samples }\end{array}$ & $\begin{array}{l}\text { No of } \\
\text { isolates } \\
(\%)\end{array}$ & $\begin{array}{l}\text { No of } \\
\text { samples }\end{array}$ & $\begin{array}{l}\text { No of } \\
\text { isolates } \\
(\%)\end{array}$ & $\begin{array}{l}\text { Total no } \\
\text { of } \\
\text { samples }\end{array}$ & $\begin{array}{l}\text { No of isolates } \\
(\%)\end{array}$ \\
\hline $0-10$ & 2 & $2(100)$ & 2 & $02(100)$ & 4 & $4(100)$ \\
$11-20$ & 4 & $4(100)$ & 08 & $08(100)$ & 12 & $12(100)$ \\
$21-30$ & 12 & $12(100)$ & 42 & $34(81)$ & 54 & $46(85.2)$ \\
$31-40$ & 16 & $11(69)$ & 68 & $46(70)$ & 84 & $60(71)$ \\
$41-50$ & 08 & $6(75)$ & 10 & $2(80)$ & 18 & $8(78)$ \\
$51-60$ & 06 & $3(50)$ & 06 & $2(50)$ & 12 & $6(50)$ \\
$61-70$ & 08 & $8(100)$ & 04 & $2(100)$ & 12 & $12(100)$ \\
$71-80$ & 02 & $2(100)$ & 02 & $2(100)$ & 04 & $4(100)$ \\
\hline TOTAL & 58 & 48 & 142 & 112 & 200 & 160 \\
\hline
\end{tabular}


Gram-negative organisms were the most common isolates among the surgical site infections pathogens with Escherichia coli having the highest prevalence $(32.5 \%)$. This was followed by Staphylococcus aureus, (28.75\%). Enterococcus species and $\alpha$-haemolytic streptococcus species were the least observed. (Table 2).

We noted that more than half of the isolates were from the obstetrics and gynaecology patients with Escherichia coli and Staphylococcus aureus having equal frequencies. The lowest number of samples were from Children's ward where the only organisms isolated were $\alpha$-hemolytic Streptococcus.

Antibiotics resistance was demonstrated by both the Gram-positive and gram-negative ones. The third generation cephalosporins and fluoroquinolnes had the highest antibacterial activity against both sets of organisms isolated. The antibacterial activity of cloxacillin and erythromycin against these pathogens was discovered to be particularly poor (Tables 4 and $5)$.
Table 2: Frequency distribution of isolate

\begin{tabular}{|l|c|}
\hline \multicolumn{1}{|c|}{ Organism } & No (\%) \\
\hline Proteus spp & $18(11.25)$ \\
Klebsiella spp & $14(8.75)$ \\
Escherichia coli & $52(32.5)$ \\
Pseudomonas spp & $26(16.25)$ \\
Staphylococcus aureus & $46(28.75)$ \\
Enterococcus spp & $02(1.25)$ \\
$\alpha$ - haemolytic streptococcus & $02(1.25)$ \\
\hline
\end{tabular}

Table 3: Distribution of bacteria isolated by wards.

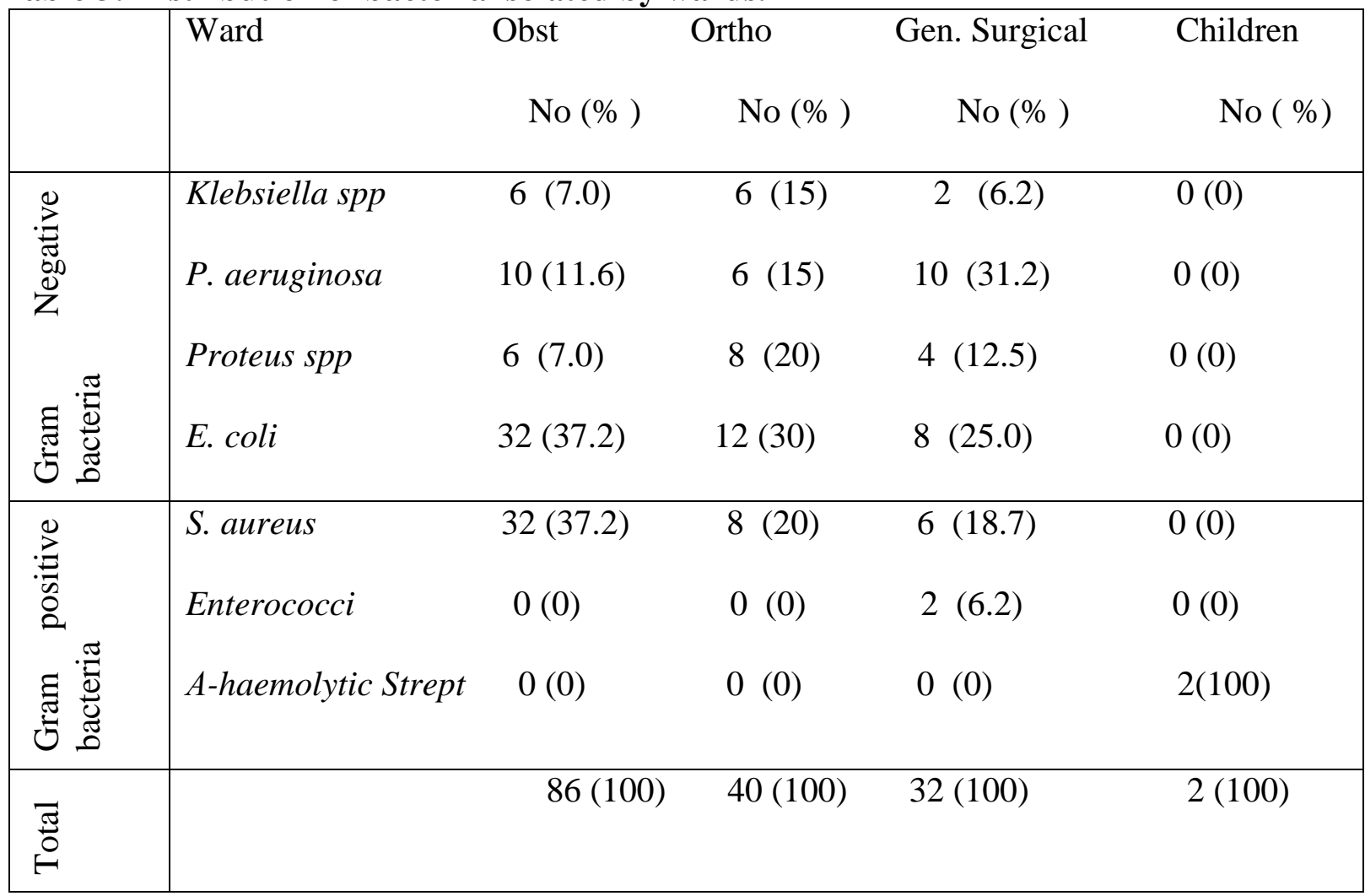


Obst- Obstetrics ward

Ortho- Orthopaedics ward

Children- Paediatrics ward

Table 4: Antibiotics susceptibility pattern of Gram-positive isolates

\begin{tabular}{|c|c|c|c|c|}
\hline Antibiotic & 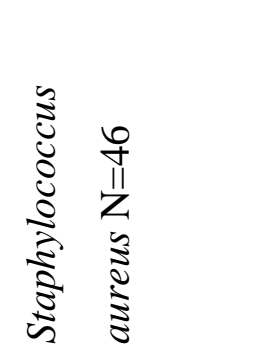 & 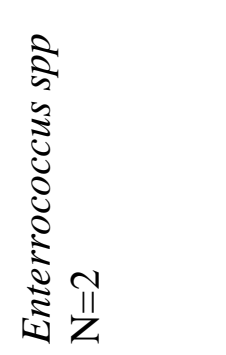 & 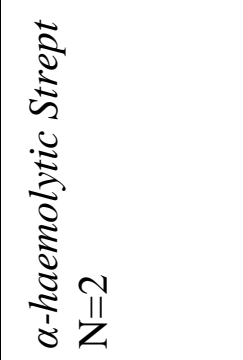 & हैं \\
\hline & $\begin{array}{ll}\text { No } & \text { sensitive } \\
(\%) & \end{array}$ & $\begin{array}{l}\text { No sensitive } \\
(\%)\end{array}$ & $\begin{array}{l}\text { No sensitive } \\
(\%)\end{array}$ & $\%$ sensitive \\
\hline Amoxicllin & $32(70)$ & $2(100)$ & $2(100)$ & $72 \%$ \\
\hline Cloxacillin & $10(22)$ & $2(100)$ & $2(100)$ & $28 \%$ \\
\hline Cotrimoxazole & $40(87)$ & $2(100)$ & $2(100)$ & $88 \%$ \\
\hline Erythromycin & $14(30)$ & $2(100)$ & $2(100)$ & $36 \%$ \\
\hline Gentamycin & $26(57)$ & $2(100)$ & $2(100)$ & $60 \%$ \\
\hline Augmentin & $39(85)$ & $2(100)$ & $2(100)$ & $86 \%$ \\
\hline Ceftriaxone & $42(91)$ & $2(100)$ & $2(100)$ & $92 \%$ \\
\hline Cefuroxime & $38(83)$ & $2(100)$ & $2(100)$ & $84 \%$ \\
\hline Ciprofloxacin & $43(93)$ & $2(100)$ & $2(100)$ & $94 \%$ \\
\hline Ofloxacin & $44(96)$ & $2(100)$ & $2(100)$ & $96 \%$ \\
\hline
\end{tabular}

\section{Discussion}

In our study, conducted in South-Western Nigeria, records Gram-negative organisms constituted $69 \%$ of the bacterial agents of surgical site infections and the remaining $31 \%$ was constituted by Gram-positive bacteria. There were no mixed infections as all samples had a single causative agent. This is in contrast to the findings of Giacometti et al in which mixed organisms were found in over half of the study population [5] The predominant organism 
isolated was Escherichia coli, as it had the highest prevalence with $32.5 \%$. E. coli is one of the predominant causes of SSI and has been documented in many studies in keeping with our findings [15]. In the present study, it was more associated with Obstetric infections unlike another study in a similar environment where Staphylococcus aureus was the predominant organism in among their Obstetrics infections [16]

Table 5: Antibiotics susceptibility pattern of Gram-negative isolates

\begin{tabular}{|c|c|c|c|c|c|}
\hline Antibiotic & 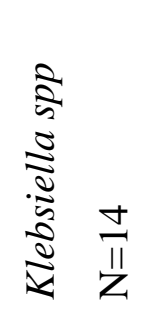 & $\begin{array}{ll}\frac{2}{5} & \\
5 & \\
\vdots & \\
0 & \infty \\
0 & 11 \\
0 & \text { Z }\end{array}$ & 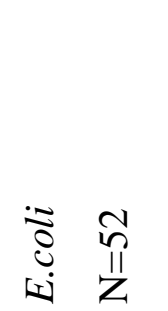 & 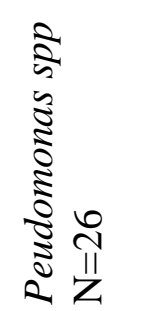 & $\stackrel{5}{0}$ \\
\hline & $\begin{array}{l}\text { No } \\
\text { sensitive } \\
(\%)\end{array}$ & $\begin{array}{l}\text { No } \\
\text { sensitive } \\
(\%)\end{array}$ & $\begin{array}{l}\text { No } \\
\text { sensitive } \\
(\%)\end{array}$ & $\begin{array}{l}\text { No } \\
\text { sensitive } \\
(\%)\end{array}$ & $\%$ sensitive \\
\hline Gentamycin & $6(43)$ & $4(22)$ & $36(69)$ & $14(54)$ & $56.3 \%$ \\
\hline Augmentin & $8(57)$ & $10(56)$ & $42(81)$ & $6(23)$ & $68.1 \%$ \\
\hline Ceftriaxone & $12(86)$ & $15(83)$ & $37(71)$ & $24(92)$ & $83.8 \%$ \\
\hline Ceftazidime & $12(86)$ & $12(67)$ & $38(73)$ & $20(77)$ & $78.8 \%$ \\
\hline Cefuroxime & $9(64)$ & $10(56)$ & $14(27)$ & $10(38)$ & $53.1 \%$ \\
\hline Ciprofloxacin & $10(71)$ & $16(89)$ & $47(90)$ & $18(69)$ & $86.2 \%$ \\
\hline Ofloxacin & $12(86)$ & $14(78)$ & $40(77)$ & $20(77)$ & $83.8 \%$ \\
\hline
\end{tabular}

Several studies have reported an increasing role of Gram-negative organisms in hospital infections as opposed to the predominance of Staphylococcus aureus in the past $[17,18,19]$. This is in keeping with our findings of a preponderance of Gram-negative bacteria as agents of surgical site infections.

Staphylococcus aureus was the most commonly isolated gram positive organism and second predominant bacteria in this study. Despite the notable shift in aetiology of SSI, this organism has remained an important nosocomial pathogen accounting for a remarkable proportion of hospital infections. Even in the present study, it had same percentage as E. coli among the obstetrics patients. The prevalence of $S$. aureus infection is similar to a previous report by Enweani. Oni et al. in Ibadan also had a similar finding although $S$. aureus was their most common organism.[20,21].

Although the Staphylococci have been established as the predominant organisms in 
orthopaedic infections due to the skin flora being the commonest contaminating organism, our finding is quite different from this fact as Escherichia coli predominated even among this group of patients [22].

The other organisms isolated were Pseudomonas species 26(16.25\%), Proteus species 18(11.25\%), Klebsiella species 14 (8.75\%), two Enterococcus spp (1.25\%) and two alpha- haemolytic streptococcus species (1.25\%) in similar to findings from other studies.

The Enterobacteriaceae as a group were the Gram-negative bacilli most commonly isolated from intra-abdominal infections. The two most commonly isolated species were $E$. coli and Klebsiella spp. These groups of organisms tend to be endemic in hospital environment, being easily transferred from object to object, they also tend to be resistant to common disinfectants and antiseptics and are difficult to eradicate in the long term playing a great role in the many hospital acquired infections [23].

This study revealed that patients at the extremes of ages had $100 \%$ bacterial growth rate. The possible explanation for this could be the established lowered immunological competence at both extremes of ages making them more susceptible to infections. Lawal et al. also had similar report [24].

Our study was limited by the fact that anaerobic culture was not done therefore no anaerobe was isolated. This limitation may account for the samples which did not yield any bacterial growth despite being sent based on clinical signs of surgical infection.

Antibiotic susceptibility testing revealed a high level of resistance of isolates to usual first line antibiotics like Amoxycillin, Cloxacillin and Co-trimoxazole which are the antibiotics that are most widely used in this environment. Multidrug resistant organisms have been widely reported in the hospital environment and in the aetiology of SSIs. The Gram negative bacteria were moderately sensitive to Gentamycin, Augmentin and the second generation Cephalosporins but showed higher susceptibility to the third generation Cephalosporins and Fluoroquinolones in contrast to findings from another environment [15]. The degree of susceptibility is, however, not satisfactory and these organisms should be assessed for production of Extended Spectrum Beta Lactamases. ESBL producing organisms now abound and can spread easily in the hospital environment [25]

The Gram positive bacteria, however, demonstrated a more remarkable response in terms of susceptibility to Fluoroquinolones and Cephalosporins.

Although our findings appear similar to what has been recorded in other areas, this is important as it emphasizes the fact that antibiotic resistance especially in the setting of nosocomial infection is a global phenomenon, no region is left out.

In view of our findings, the Fluoroquinolones and Cephalosporins are therefore the preferred antibiotics for effective management of patients with surgical site infections.

\section{Conclusion}

From this study, there is a high prevalence of multidrug resistant organisms causing SSI, a good marker of Hospital Acquired Infection (HAI). Prevention, in the form of adequate infection surveillance, ensuring standard aseptic techniques as well proper preparation and maintenance of operating room are very important in addition to antibiotic policy based on susceptibility profile of infecting agents.

\section{Acknowledgement}

The authors wish to appreciate the staff of the Department of Medical Microbiology and Parasitology, Federal Medical Centre, Abeokuta for their assistance in sample processing.

\section{References}

1. Perencevich Perencevich EN, Sands KE, Cosgrove SE, Guadagnoli E, Meara E, Platt R. Health and Economic Impact of Surgical Site Infections Diagnosed after Hospital Discharge. Emerging Infectious Diseases 2003; 9: 196-203. DOI: $\underline{10.3201 / \text { eid0902.020232 }}$ 
2. Collier M. Recognition and management of wound infections. World Wide Wounds (ejournal) 2004

3. Martone W, Jarvis W, Edwards J, Culver D, Haley R. Incidence and nature of endemic and epidemic nosocomial infections. In: Bennet JV, Brachman PS, eds. Hosp Infect. Philadelphia: Lippincott-Raven 1998.

4. DiPiro JT, Martindale RG, Bakst A, Vacani PF. Infection in surgical patients; effects on mortality, hospitalization and post discharge care. American Journal of Health System Pharmacy 1998; 55: 777-81.

5. Giacometti A, Cirioni O, Schimizzi AM, Del Prete MS, Barchiese F, Derrico MM, Petrelli E, Scalise G. Epidemiology and microbiology of surgical wound infections. Journal of Clinical Microbiology .2000; 38: 918- 22.

6. Nichols RL. Postoperative infections in the age of drug resistant gram positive bacteria. American Journal of Medicine 1998; 104: 115- $65 . \quad$ DOI: $10.1016 / \mathrm{S} 0002-$ 9343(98)00150-8

7. Cruse PJ, Foord R. The epidemiology of wound infection; A ten year prospective study 62,939 wounds; Surgical Clinics of North America 1980; 60: 27-40

8. Cruse PJE. Classification of operations and audit of infection. In: Infection in surgical practice. Oxford. Oxford University press 1992

9. Gottrup F. Wound closure techniques. Journal of Wound Care 1999; 8: 397-400.

10. Buggy D. Can anaesthetic management influence surgical wound healing? Lancet 2000; 356:355- 7. DOI: 10.1016/S01406736(00)02523-X

11. Oguntibeju O, Nwobu RAU. Occurrence of Pseudomonas aeruginosa in post operative wound infection. Pakistan Journal of Medical Sciences 2004; 20(3): 187-191.

12. Cowan SF, Steel KJ. Manual for the Identification of the Medical Microorganism. Cambridge: Cambridge University Press. 1970

13. Bauer AW, Kirby WM, Sherries JC, Jurik M. Antibiotic susceptibility testing by a standard single disc method. American Journal Clinical Pathology 1996; 451: 493- 6.

14. National Committee for Clinical Laboratory Standards. Performance Standards for Antimicrobial Susceptibility Testing: Twelfth Informational Supplement M100-S12 2002. Villanova, PA, USA. National Committee for Clinical Laboratory Standards

15. Shahane V, Bhawal S, Lele U. Surgical site infections: A one year prospective study in a tertiary care center. International Journal Health Sciences (Qassim). 2012;6(1):79-84.

16. Jido TA, Garba ID. Surgical site infection following Cesarean section in Kano, Nigeria. Annals of Medical and Health Sciences Research. 2012. 2;1: 33-36. PMID:23209988. DOI: $10.4103 / 2141-9248.96934$

17. Mangram AJ. Horan TC, Pearson ML, et aI. "Guideline for Prevention of Surgical Site Infection 1999" issued by ('Centers for Disease Control and Prevention through its 12 member Hospital Infection Control Practices Advisory Committee. Am J Infect Control 1999; 27:27-30.

18. Andreassenn JJ, Korsauger B, Alstrup P, Jepsen OB. Post-operative wound infection: indicator of clinical quality? Danish Medical Bulletin 2002; 49: 242-4.

19. Sule AM, Thanni LOA, Sule O, Olusanya O. Bacterial pathogens associated with infected wounds in Ogun State University Teaching Hospital Sagamu, Nigeria. African Journal of Clinical and Experimental Microbiology. 2002; 3: 13-16. DOI: 10.4314/ajcem.v3i1.7344

20. Enweani, U N. Surgical wound sepsis in clean orthopaedic procedures: bacteriology and sensitivity pattern in a regional specialist centre. Orient Journal of Medicine 1991; 3: 1-6

21. Oni AA, Ewete AF, Gbaja AT, Kolade AF, Mutiu WB, Adeyemo DA, Bakare RA. Nosocomial infections; surgical site infection in UCH, Ibadan, Nigeria. Nigerian Journal of Surgical Research 2006; 8(1): 19-23. DOI: 10.4314/njsr.v8i1.54850.

22. Guide to the Elimination of Orthopedic Surgical Site Infections. An APIC Guide. 2010. Accessed from 
http://www.apic.org/Resource /EliminationG uideForm/34e03612-d1e6-4214-a76b-

e532c6fc3898/File/APIC-Ortho-Guide.pdf on 5 may 2013

23. Ayliffe G, Babb J, Taylor LJ. The hospital environment. In: Ayliffe G, Babb J, Taylor LJ. Hospital acquired infection: principles and prevention. 3rd ed. Oxford: ButterworthHeinmann 1999

24. Lawal, OO, Adejuyigbe O, Oluwole ST. The Predictive value of bacterial contamination of operation in Post operative wound sepsis. African Journal of Medicine and Medical Sciences 1990; 19:173- 9.

25. Dhillon RH, Clark J. ESBLs: A clear and present danger? Critical Care Research and Practice. 2012; 1-11. PMid:21766013 DOI: $\underline{10.1155 / 2012 / 625170}$ 